\title{
Prevalence of Maxillary Central Incisor Impaction and Supernumerary Teeth among Nepalese Orthodontic Patients
}

\author{
Dr Dashrath Kafle,' Dr Sita Shrestha, ${ }^{2}$ Dr Nisha Acharya, ${ }^{3}$ Dr Aaradhana Agarwal4 \\ 'Assistant Professor, 4Lecturer, Dept of Orthodontics, 3Lecturer, Dept of Endodontics, ${ }^{2}$ Dental Surgeon \\ Kathmandu University School of Medical Sciences, Dhulikhel, Nepal
}

Correspondence: Dr Dashrath Kafle Email: dashrathoך@yahoo.com

\section{ABSTRACT}

Introduction: Very few studies have been done on impacted maxillary central incisors and supernumerary teeth.

Objective: To find the prevalence of maxillary central incisor impaction and supernumerary teeth among orthodontic patients attending Dhulikhel Hospital, Kathmandu University Teaching Hospital.

Materials \& Method: The retrospective study consisted of 787 records of orthodontic patients of age 10-35 years. Dental model and orthopantomograph were retrieved and searched for impacted maxillary central incisors and supernumerary teeth. Incomplete records and patients with known syndromes were excluded from the study. Descriptive statistics was applied to find the prevalence rate and comparison between male and female was done by chi-square test.

Result: Out of total samples, $14(1.8 \%)$ and $11(1.4 \%)$ samples were found to have impacted maxillary central incisors and supernumerary teeth respectively. There was no significant difference in prevalence of impacted maxillary central incisors between male and female samples $(p=0.78)$, however there was significant difference in occurrence of supernumerary teeth between gender groups $(p=0.025)$.

Conclusion: The prevalence of impacted maxillary central incisor and supernumerary teeth among orthodontic patients attending Dhulikhel Hospital, Kathmandu University Teaching Hospital is $1.8 \%$ and $1.4 \%$ respectively. Male patients have higher chance of having supernumerary teeth than female patients.

Keywords: impaction, maxillary central incisor, prevalence, supernumerary teeth

\section{INTRODUCTION}

Impacted tooth is the one which fails to appear into the oral cavity beyond the expected time of eruption and its contralateral antimere has erupted six months earlier. The most commonly impacted teeth are mandibular third molars followed by maxillary canines, mandibular second premolars and maxillary central incisors. ${ }^{1-5}$ Though there are not many studies on maxillary central incisor impaction, the prevalence of maxillary central incisor impaction has been reported to be between $0.06-3 \% .6{ }^{6-9}$ The aetiologies of maxillary central incisor impaction are grossly divided into obstructive and traumatic causes. ${ }^{10}$ The obstructive pathologies are: presence of supernumerary teeth on the path of eruption, odontomes, cysts and tumours. Traumatic causes are obstruction due to soft tissue repair, dilacerations, arrested root development and intrusive luxation. ${ }^{10}$ The most common cause of maxillary central incisor impaction is the presence of midline supernumerary tooth. ${ }^{11-13} \mathrm{~A}$ recent study by Fardi et al reported the prevalence of supernumerary teeth as $1.8 \%$ in which majority were mesiodens. Becker mentioned that $0.42-2.1 \%$ of the pediatric patients sufferred from impacted central incisor because of midline supernumerary teeth. The management of impacted maxillary incisors are challenging many a times. Though there are very few research papers conducted on this aspect, there are plenty of case reports on management of impacted maxillary impacted central incisors. ${ }^{14-21}$ The objective of present study is to find the prevalence of maxillary central incisor impaction and supernumerary teeth in patients seeking orthodontic treatment at Dhulikhel Hospital, Kathmandu University Teaching Hospital (DH, KUTH).

\section{MATERIALS AND METHOD}

Orthodontic records comprising of dental model and orthopantomograph of 787 orthodontic patients (male 308, female 479) of the age ranging from 10-35 years were retrieved from the Department of Orthodontics, DH, KUTH for the purpose of study. Incomplete records and records of syndromic patients were excluded from the study. Initially patient's age and sex were determined then visual examination of dental model was done followed by OPG examination. The samples were grouped into three groups according to age: 10-15 years (N1), 16-25 years (N2) and 26-35 years (N3). The number of teeth was counted from the midline till last erupted tooth. The data was 
Table 1: Distribution of impacted maxillary central incisor and supernumerary teeth among orthodontic patients

\begin{tabular}{|l|c|c|c|c|c|c|}
\hline \multicolumn{1}{|c|}{ Sample } & $\mathbf{N}$ & $\begin{array}{c}\mathbf{N 1} \\
(\mathbf{1 0 - 1 5} \mathbf{y r s})\end{array}$ & $\begin{array}{c}\mathbf{N 2} \\
(\mathbf{1 6 - 2 5} \mathbf{y r s})\end{array}$ & $\begin{array}{c}\text { N3 } \\
(\mathbf{2 6 - 3 5} \mathbf{y r s})\end{array}$ & $\begin{array}{c}\text { Impacted mx } \\
\text { central incisor }\end{array}$ & $\begin{array}{c}\text { Supernumerary } \\
\text { teeth }\end{array}$ \\
\hline Male & $308(39.1 \%)$ & $105(34.4 \%)$ & $163(52.9 \%)$ & $40(12.9 \%)$ & $6(1.9 \%)$ & $8(2.5 \%)$ \\
\hline Female & $479(60.9 \%)$ & $140(29.2 \%)$ & $265(55.3 \%)$ & $74(15.4 \%)$ & $8(1.6 \%)$ & $3(0.6 \%)$ \\
\hline Total & 787 & $245(31.1 \%)$ & $428(54.3 \%)$ & $114(14.4 \%)$ & $14(1.8 \%)$ & $11(1.4 \%)$ \\
\hline
\end{tabular}

Table 2: Comparison of gender groups on occurrence of impacted maxillary central incisors and supernumerary teeth

\begin{tabular}{|l|c|c|c|}
\hline & Male $(\mathbf{N}=\mathbf{3 0 8})$ & Female $(\mathbf{N}=\mathbf{4 7 9})$ & p-value \\
\hline Impacted maxillary central incisors & 6 & 8 & 0.78 \\
\hline Supernumerary teeth & 11 & 8 & $0.025^{*}$ \\
\hline
\end{tabular}

*Significant $p<0.05$

fed into SPSS version 16 and descriptive statistics was applied to find the prevalence of maxillary central incisor impaction and supernumerary teeth among total samples and according to the gender. Statistical analysis was done using chi-square test to assess the difference between male and female groups on occurrence of central incisor impaction and supernumerary teeth, at a significance level $p<0.05$.

\section{RESULT}

Out of 787 patients $39.1 \%$ were male and $60.9 \%$ were female. Majority of the patients were of the age group 16-25 years, followed by 10-15 years. The present study found that, 14 patients (1.8\%) had impacted maxillary central incisor and 11 patients (1.4\%) had supernumerary teeth. The prevalence of impacted maxillary central incisor and supernumerary teeth according to gender and age group is given in Table 1.

According to the study, there was no significant difference between male and female samples on occurrence of maxillary incisor impaction $(p=0.788)$. However, there was statistically significant difference on occurrence of supernumerary teeth when comparison was made between gender groups $(p=0.025)$ (Table 2).

\section{DISCUSSION}

The prevalence of impacted maxillary central incisor is found to be $1.8 \%$ among Nepalese orthodontic patients. There are very few studies on prevalence of impacted maxillary central incisors. Grover and Lorton reported $0.06-0.2 \%$ in general population. " It was found to be $2.4 \%$ in a hospital-based study in Malaysia. ${ }^{22}$ The present study further compared the occurrence of impacted maxillary central incisors between male and female samples; which was $1.9 \%$ and $1.6 \%$ respectively. Males have slightly higher predilection though not statistically significant. There are various aetiological factors of impaction of maxillary central incisors. One of the most common reasons is the presence of supernumerary tooth/teeth in the midline causing obstruction on the path of eruption. It has been reported that up to $60 \%$ of the supernumeraries are found to be located in the premaxilla region. ${ }^{12,23-26}$ In our study, the prevalence of supernumerary teeth is $1.4 \%$. Almost similar result was found in different studies. ${ }^{10-13}$ Contrary to our finding, a Brazilian study on cleft lip patients found the presence of supernumerary teeth in $29 \% .{ }^{27}$ Regarding the prevalence of supernumerary teeth, our study found that male samples had higher chance of having supernumeraries than females; which is well supported by the number of other researches. ${ }^{23-26}$

\section{CONCLUSION}

The prevalence of impacted maxillary central incisor and supernumerary teeth among orthodontic patients at Dhulikhel Hospital, Kathmandu University Teaching Hospital is $1.8 \%$ and $1.4 \%$ respectively. There is no statistical difference between the gender groups on prevalence of maxillary central incisor impaction. Male samples tend to have more occurrences of supernumerary teeth than females. 


\section{REFERENCES}

1. El-Khateeb SM, Arnout EA, Hifnawy T. Radiographic assessment of impacted teeth and associated pathosis prevalence. Pattern of occurrence at different ages in Saudi male in Western Saudi Arabia. Saudi Med J. 2015; 36(8):973-9.

2. Pedro FL, Bandeca MC, Volpato LE, Marques AT, Borba AM, Musis CR. Prevalence of impacted teeth in a Brazilian subpopulation. J Contemp Dent Pract. 2014; 15(2):209-13.

3. Patil S, Maheshwari S. Prevalence of impacted and supernumerary teeth in the North Indian population. J Clin Exp Dent. $2014 ; 6$ (2): 1 16-20.

4. Topkara A, Sari Z. Impacted teeth in a Turkish orthodontic patient population: Prevalence, distribution and relationship with dental arch characteristics. Eur J Paediatr Dent. 2012; 13(4):311-6.

5. Gisakis IG, Palamidakis FD, Farmakis ET, Kamberos G, Kamberos S. Prevalence of impacted teeth in a Greek population. J Investig Clin Dent. $2011 ; 2(2): 102-9$.

6. Brin I, Zilberman Y, Azaz B. The unerupted maxillary central incisor: Review of its etiology and treatment. ASDC J Dent Child. 1982; $49(5): 352-6$

7. Zilberman Y, Malron M, Shteyer A. Assessment of 100 children in Jerusalem with supernumerary teeth in the premaxillary region. ASDC J Dent Child. 1992; 59(1):44-7.

8. MacPhee CG. The incidence of erupted supernumerary teeth in consecutive series of 4000 school children. Br Dent J 1935; $58: 59-60$.

9. Grover PS, Lorton L. The incidence of unerupted permanent teeth and related clinical cases. Oral Surg Oral Med Oral Pathol. 1985; 59(4):420-5.

10. Becker A, editor. Orthodontic treatment of impacted teeth. 3rd ed: Willey-Blackwell; 2012.

11. Smailiene D, Sidlauskas A, Bucinskiene J. Impaction of the central maxillary incisor associated with supernumerary teeth: Initial position and spontaneous eruption timing. Stomatologija. 2006; 8(4):103-7.

12. Tay F, Pang A, Yuen S. Unerupted maxillary anterior supernumerary teeth: Report of 204 cases. ASDC J Dent Child. 1984; 51 (4):289-94.

13. Mathias MF, Lobo-Piller RG, Correa MS. Treatment of supernumerary teeth. Eur J Paediatr Dent. 2011; 12(4):275-8.

14. Cozza P, Mucedero M, Ballanti F, De Toffol L. A case of an unerupted maxillary central incisor for indirect trauma localized horizontally on the anterior nasal spine. J Clin Pediatr Dent. 2005; 29(3):201-3.

15. Glenn FB. Case report: Twin supernumerary maxillary central incisors, unerupted maxillary central incisors. Early orthodontic treatment in ten-year-old child. J Gen Orthod. 1994; 5(1):24-7.

16. Saglam AA, Tuzum MS. Clinical and radiologic investigation of the incidence, complications, and suitable removal times for fully impacted teeth in the Turkish population. Quintessence Int. 2003; 34(1):53-9.

17. Ayers $E$, Kennedy D, Wiebe C. Clinical recommendations for management of mesiodens and unerupted permanent maxillary central incisors. Eur Arch Paediatr Dent. 2014; 15(6):421-8.

18. Yeung KH, Cheung RC, Tsang MM. Compound odontoma associated with an unerupted and dilacerated maxillary primary central incisor in a young patient. Int J Paediatr Dent. 2003; 13(3):208-12.

19. Kajiyama K, Kai H. Esthetic management of an unerupted maxillary central incisor with a closed eruption technique. Am J Orthod Dentofacial Orthop. 2000; 118(2):224-8.

20. Montalvo-Polk A, Kittle PE. Impaction and malformation of a maxillary central incisor: sequelae of trauma. ASDC J Dent Child. 1993; 60(1):29-32.

21. Fardi A, Kondylidou-Sidira A, Bachour Z, Parisis N, Tsirlis A. Incidence of impacted and supernumerary teeth - A radiographic study in a North Greek population. Med Oral Patol Oral Cir Bucal. 2011 ; 16(1):56-61.

22. CPG secretariat $\mathrm{c} / \mathrm{O}$ health technology assessment unit. Management of unerupted maxillary incisor, Clinical practice guideline. Malaysia, http://www.moh.gov.my [Cited 20 July 2008].

23. Demiriz L, Durmuslar MC, Misir AF. Prevalence and characteristics of supernumerary teeth: A survey on 7348 people. J Int Soc Prev Community Dent. 2015; 5(Suppl 1):39-43.

24. Anegundi RT, Tegginmani VS, Battepati P, Tavargeri A, Patil S, Prasad V. Prevalence and characteristics of supernumerary teeth in a nonsyndromic South Indian pediatric population. J Indian Soc Pedod Prev Dent. 2014; 32(1):9-12.

25. Celikoglu M, Kamak H, Oktay H. Prevalence and characteristics of supernumerary teeth in a non-syndrome Turkish population: Associated pathologies and proposed treatment. Med Oral Pathol Oral Cir Bucal. 2010; 15(4):575-8.

26. Arikan V, Ozgul BM, Firdevs TO. Prevalence and characteristics of supernumerary teeth in a child population from Central Anatolia Turkey. Oral Health Dent Manag. 2013; 12(4):269-72.

27. deSilva AP, Costa B, deCarvalho Carrara CF. Dental anomalies of number in the permanent dentition of patients with bilateral cleft lip: radiographic study. Cleft Palate Craniofac J. 2008; 45(5):473-6. 